\title{
Migrating Football Players, TRAnsfer FEES AND MIGRATION CONTROLS
}

\author{
HARRIE A. A. VERBON \\ CESIFO WORKING PAPER NO. 2004 \\ CATEGORY 1: PUBLIC FinANCE \\ MAY 2007
}

An electronic version of the paper may be downloaded

- from the SSRN website:

wWw.SSRN.com

- from the RePEc website:

www.RePEc.org

- from the CESifo website:

www.CESifo-group.de 


\title{
Migrating FoOtBall Players, TRANSFER FEES AND MigRATION CONTROLS
}

\begin{abstract}
Since the famous Bosman ruling by the European Court of Justice in 1995 transfer fees for football players after moving to another club have become suspect as they are considered as an obstacle to the free movement of workers. However, in an unrestricted market free migration from football players will be Pareto efficient under special circumstances only. This paper shows that transfer fees can correct inefficient migration flows from small to large football leagues. Home-grown rules that prescribe that a certain proportion of the roster of players should be trained within the club are very blunt devices for restoring efficiency, and perform worse than transfer fee systems.
\end{abstract}

JEL Code: H77, J61, L83.

Keywords: football transfers, migration equilibrium, social welfare.

Harrie A. A. Verbon

Tilburg University

Department of Economics

P.O. Box 90153

5000 LE Tilburg

The Netherlands

H.A.A.Verbon@uvt.nl

9 May 2007 


\section{Introduction}

A major concern for managers of team sports leagues is simultaneously maintaining the competitive balance between the teams comprising the league, and remaining competitive with respect to other leagues. The latter requirement is necessary in order to remain able to attract talented players who are raised or playing in other leagues. The former requirement is realized if the distribution of talents among the teams is relatively homogeneous. Traditionally, league managers have sought to safeguard competitive balance within the league by controlling the market for players. For instance, in the European football leagues it has long been common practice to assume the clubs to be the owners of players they have under contract. Even after a contract expired players were not entitled to play for another club without permission of their former club. This club was even allowed to demand financial compensation for a change in club by a former player. This practice ended with the so-called 1995 Bosman judgment by the Court of Justice of the European Union, ruling that transfer fees after the expiration of a contract were an obstacle to the free movements of workers, one of the fundamental rights upon which the European Union is based.

Another mechanism to maintain competitive balance is by proportional redistributing revenues from ticket sales or broadcasting rights. The 'small' clubs are thus being prevented from getting poorer. This practice has been common in the major US sports leagues (Szymanski, 2003), but in the economics sports literature its effectiveness has been questioned. According to the so-called invariance principle (El-Hodiri and Quirk, 1971) the distribution of talent among clubs will be biased towards the big clubs, and measures to curb free mobility of players, like the transfer fee systems in European football, are ineffective for safeguarding competitive balance. The principle of free mobility then should be weighed more heavily as it prevents owners of competitions to abuse their monopsonistic power towards the players and the consumers.

Zymanski and Késenne (2004) even go one step further by arguing that redistribution towards the weak drawing teams will blunt the incentives for team owners to compete, since the returns to winning are reduced. In the same vein Palomino and Sakovics (2004) argue that in an environment where different leagues compete for the top star players, it is 
in the interest of each and every league to provide its teams the incentives to bid a high price for the top talents compared to foreign teams. A performance-based distribution of revenues provides such incentives.

However, an aspect that has been relatively undervalued is that most migration of players in European football has been in the direction of the 'big' leagues, i.e. England, Spain, Italy, and, to a lesser extent, Germany. After the Bosman ruling the small leagues tried to hold on to their talents by offering them long-term contracts (Fees and Muehlheuser, 2003a and 2003b), but in the end the best talents of the small leagues are playing in those big leagues.

While within one league a decline of competitive balance tends to be corrected one way or another, between leagues such an automatic correction mechanism does not seem to operate. Free mobility of players will be inefficient if the marginal loss of the small sending league is larger than the marginal benefit of the big receiving league. However, interestingly, free mobility of players can under special circumstances also lead to inefficiently low migration flows from the small to the big leagues. In particular, this is the case when talents have to be trained before they can play in the league.

It is relatively straightforward to demonstrate along the lines of the classic Boadway and Flatters (1982)-paper that in case 'big' and 'small' leagues co-exist as is the case in European football, migration flows can turn out to be inefficiently large (or, sometimes, small). Intervention from the federal (football) authority is therefore necessary in order to restore efficiency. These interventions can be financial measures like redistributing revenues from the big and rich leagues to the small and poor leagues. In this circumstance an 'old-fashioned' transfer fee system can provide a correction to inefficient migration flows of football players. In case migration is too large, these transfer fees are comparable to the equalization transfers in the fiscal-federalism literature (see Boadway, 2004, for an overview) from better-off to less well-off jurisdictions. If the number of talents in each league is exogenously given, transfer payments for the emigration of talents correct an inequitable distribution of welfare across leagues. In general, the optimal transfer fee rate is a positive function of players' capability, a negative function 
of the relative size of the home country of the talents, and should moreover be relatively high when talents are in high demand.

But, direct or indirect migration controls can also be used to restore efficiency. Previously such controls were realized in European football by the so-called nationality rule. This rule allowed national football associations to limit the number of foreign players a team in a given association was allowed to field. By regulating the maximum number of foreign players, migration of players was effectively restricted and the quality of the smaller leagues protected. It goes without saying that within the common market of the EU, this practice had to be abolished. Indeed, as a part of the Bosman ruling, the European Court of Justice also held that the nationality rule constituted an obstacle to the freedom of movement and was therefore prohibited.

Another example of a migration control is the so-called 'home-grown' player rule, recently introduced by the European Football Association (UEFA). According to this rule, clubs can only enter a European competition, like the Champions League, if their roster of players contains at least a certain number of players who were educated by the club itself. This rule obviously restricts the demand for foreign players and thus restricts migration in an indirect way. However, as in the current formulation of the home-grown rule the nationality of the trained players is left unidentified, the rule is not necessarily an infringement upon EU principles. Recently, the European Parliament even explicitly has declared itself in favor of the home-grown rule as a means to restore competitive balance in European football.

If talents are to be trained in order to become top players, free and uncompensated migration of players will diminish the incentives for national leagues to provide schooling to talented players. As a result the supply of talents will be too low. Transfer fees can lead to a correction to a too low supply of talents because of the lack of training facilities. However, although introducing transfer fees for migrating players will be Pareto improving compared to a free market migration equilibrium of football players, oversupply of talents in the small league can emerge.

In an equilibrium with endogenous talents small leagues will not have any training facilities if the migration of their talents to the big leagues go uncompensated. The 
demand for their talents can be limited, however, if a home-grown players rule is operative. In that case, the big leagues should have their own training facilities before they can demand foreign talents. The rule, therefore, can make it advantageous for the small league to have training facilities for their talents. As we will see, however, in the context of our model, the home-grown condition should be very strong in order for the positive effect on the small league's training facility to become operative. Moreover, the primary beneficiary of a home-grown rule appears to be the big league, especially when talents are highly capable.

In the next section the basic model will be developed. In section 3 we deal with the case where talents are exogenously given, while in section 4 talents have to be trained before they can play in one of the leagues. For both cases we demonstrate the inefficiency of migration by comparing the market equilibrium with a social-welfare optimum. The fifth section concludes.

\section{The Model}

Assume two 'football leagues', a large one, in country 1, and a small one in country 2. The production value of football in country $i$ is given by $Y_{i}=N_{i} \sigma^{\alpha T_{i}}(i=1,2)$, where $T_{i} \leq 1$ represents the number of talented players in the competition, and $\sigma>1$, represent their capability assumed to be equal across talents. The maximum number of talented players, supposed to be equal to one, reflects the fixed number of players in a competition. Talents are supposed to be homogeneous in quality. That means the issue of deciding how many 'veterans' or 'rookies' should be in the line up (Terviö, 2006) is no matter of concern for the owners of the league. The variable $N_{i}$ can be thought of as the population in the country of league $i(i=1,2)$ and indicates the market size of the football product. Population size is attached as a multiplicative factor to take account of the public-good characteristics of the product, implying that in larger countries a given amount of football talent can generate a larger product, and a larger profit as a consequence, than in a small country. 
We make the implicit assumption that if the number of talents is not sufficient to man the competition, talents will be supplemented by players with a mediocre talent, having a capability equal to one, who are not paid for their services. Talents are assumed to be scarce, while non-talented players are in abundant supply. Talented players get their marginal product $\alpha Y$ paid. Time is not playing an explicit role in the model. The time horizon of the contract (Fees and Muehlheuser, 2003a and 2003b) is thus not relevant. If $T$ talents play in a competition total wage paid equals $\alpha T Y$. The parameter $\alpha<1$ indicates that the football industry is a profit generating business, so that salaries to the players do not exhaust the profit. The profits in a league are equal to the value of the

product, $Y$, minus the wages for talented and the training costs, if any, plus or minus the revenues or outlays associated with the possible existence of a transfer fee system.

The number of talents a league wants to employ follows from profit maximization. If this number is larger than the number of native talents in the league the league has the option to hire talents from the other league. Population in country 1 is larger than in country 2: $N_{1}>N_{2}$. This implies that the wage league 1 can pay to a talented player is higher than the wage league 2 can afford. We, therefore, assume that the big league always gets the talents from the small league that it wants to hire, and no negotiation with the small league is needed to hire the talent. The small league can at most employ its own native talents.

Regarding the total number of talents in the two countries we start in section 3 with the assumption that the total number of talents is exogenously given. In section 4 . we allow for the possibility that by investing in talents the number of talents present in an economy can be affected. We assume a logarithmic talent production function where an investment $e_{i} \geq 1$ produces $\delta \log e_{i}$ talents.

\section{Migration with exogenous talents}

In this section we first consider the market equilibrium in a world where talented players can freely migrate to other leagues, without any compensating transfers to be paid by the new league. The welfare properties of this market equilibrium are then derived, and, 
finally, we will consider whether a transfer fee system can correct the uncompensated market equilibrium and mimic the social-welfare optimum.

Table 1 Number of players in league 1 and welfare in both leagues $\left.{ }^{*}\right)$

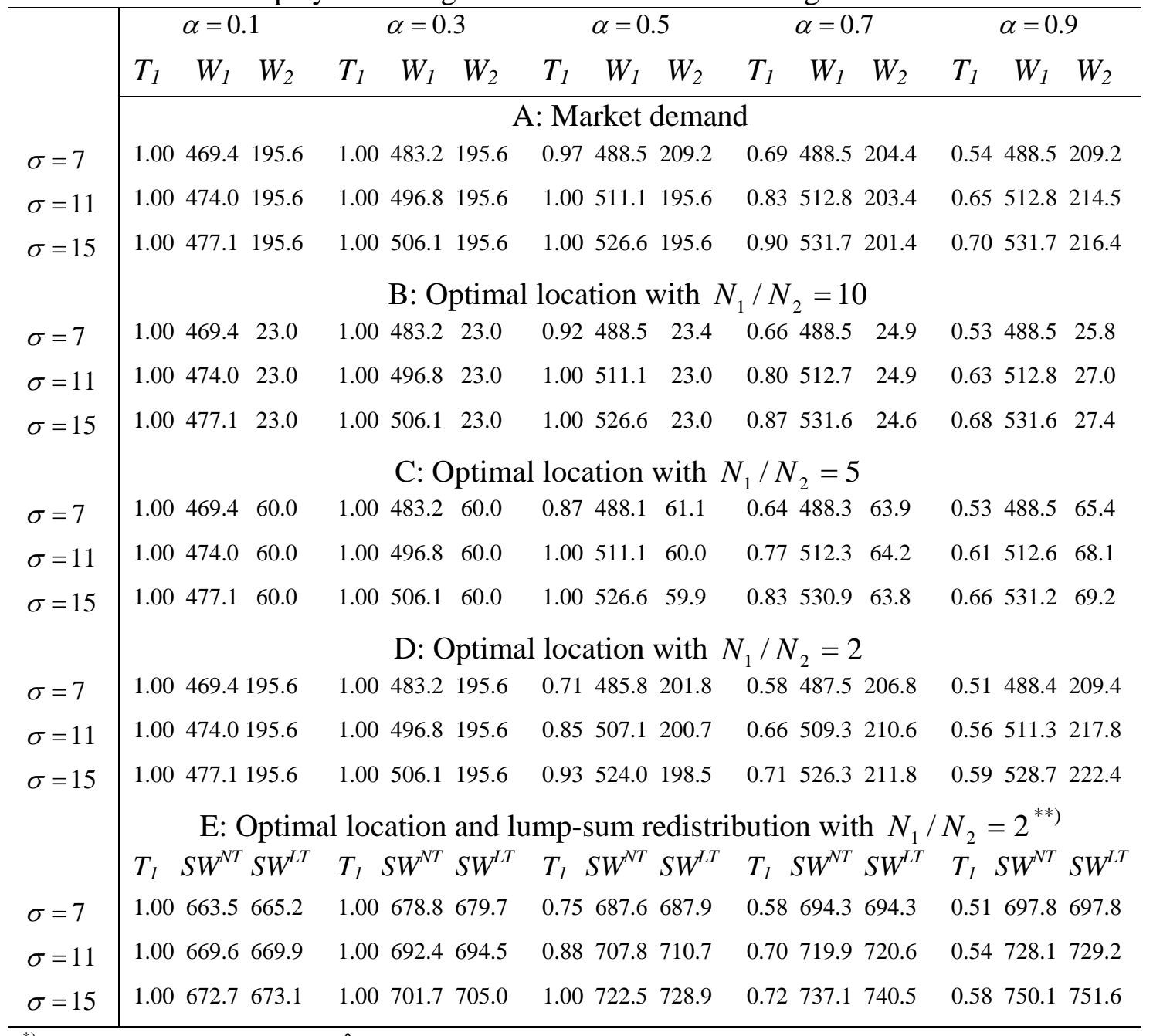

\footnotetext{
${ }^{*}$ The total number of players $\hat{T}$ is assumed to be equal to one; the big league has market size $N_{1}=100$.

The entries indicate the number of players in league $1, T_{1}$, generated by the market (Panel A); or representing the optimal number of players in league 1 calculated from eq. (2), (Panels B-D), and the welfare for the leagues, $W_{1}$ and $W_{2}$, defined by $W_{i}=N_{i} \log \Pi_{i}, i=1,2$. For the market case, $N_{2}=50$ is assumed. ${ }^{* *}$ Panel E displays the number of players and the total welfare without $\left(S W^{N T}\right)$ and with $\left(S W^{L T}\right)$ lump-sum redistributions, respectively
}

\subsection{The market without transfer fees}

The most interesting case to consider is where in the big league at least the number of talents available in the own country is less than the maximum number of players that can 
be employed in the competition, $\hat{T}_{1}<1$. where a hat $\wedge$ indicates the exogenously given number of talents in a country. As the big league can afford to pay higher wages to talents, the league has the option to 'import' talents from the small league 2 . Whether it is profitable for the big league to supplement their own talents by talents from the other league follows from profit maximization. The profit obtained by league 1 equals $\Pi_{1}=Y_{1}\left(1-\alpha T_{1}\right)$. Profit maximization will lead to a demand for talented players equal to $T_{1}=(1-1 / \log \sigma) / \alpha$.

Notice that the demand for players is a decreasing function of $\alpha$ and an increasing function of $\sigma$, but is independent of market size. Moreover, if an interior solution holds, i.e. $T_{1}<1$, profit only depends on $\sigma$, while the assumed scarcity of talents will hold as long as $(1-1 / \log \sigma) / \alpha>\left(\hat{T}_{1}+\hat{T}_{2}\right) / 2$. Finally, the demand by league 1 will imply a complete manning of the league with talented players, i.e., $T_{1}=1$, if $\alpha<1-1 / \log \sigma$.

The effects of changes in the parameters on the allocation of talents can be read off from panel A of Table 1 that illustrates the relationship between the market allocation and the key parameters of our model of the football market, i.e., the profitability of the football industry, the size of the market and players' capability. In Table 1 the total number of available talents for both leagues together is equal to one. If the demand for talents is high ( $\alpha=0.1$ or $\alpha=0.3$ ) the market locates all the talents to the big league. For a median value of $\alpha$, i.e., $\alpha=0.5$ league 1 demands all the talents only if their capability is high ( $\sigma=11$ or $\sigma=15$ ). For low demand ( $\alpha=0.7$ or $\alpha=0.9$ ) league 2 will receive some of the talents, but this amount will decrease with rising players’ capability.

\subsection{The social optimum: the efficient allocation of players}

Given symmetry in the parameters $\alpha$ and $\sigma$ for both leagues, the demand for talents will be the same in the two leagues. The market, however, allocates most of the players to league 1, implying that league 1 can, but league 2 cannot maximize its profits. From a social welfare perspective this migration equilibrium can be motivated if the welfare gain for country 1 from the immigration of the marginal talented player is larger than the welfare loss for country 2 from the emigration of this player from country 2. In the context of our model and given our parameter choice this will actually never be the case. 
In other words, the market equilibrium will not be a social optimum. The reason for the possibility of a non-optimal migration equilibrium has been known for quite some time in the fiscal-federalism literature (see, e.g., Boadway and Flatters, 1982 and the recent survey by Boadway, 2004). In particular, in accepting the wage offer from the large league the talents disregard the loss in the profit per capita they inflict on the owners of the small country.

To elaborate this point, we assume that the inhabitants of the two countries are the owners of the competition, and that the profit generates an individual utility equal to $\log \Pi_{i}$. Moreover, a federal football institution (FFI), like the UEFA in European football, exists that takes the utility of both league owners into account. This institution maximizes social welfare that is equal to

$$
W=N_{1} \log \Pi_{1}+N_{2} \log \Pi_{2}
$$

The total number of players equals $\hat{T}_{1}+\hat{T}_{2}=\hat{T}$. The FFI can calculate the optimal allocation of the $\hat{T}$ talented players among the two leagues, assuming an interior solution, by equating the marginal benefit of immigration for league 1 with the marginal loss of immigration for league 2, which for this case can be written as:

$$
M B_{1} \equiv N_{1}\left(\alpha \log \sigma-\frac{\alpha}{1-\alpha T_{1}}\right)=N_{2}\left(\alpha \log \sigma-\frac{\alpha}{1-\alpha T_{2}}\right) \equiv M B_{2}
$$

To learn whether condition (2) holds, consider first the case when the market generates an interior solution $T_{1}<1$, i.e. $\alpha=0.5$ and $\sigma=7, \alpha=0.7, \alpha=0.9$. Insert the market demand for talents in league 1 into the definition of $M B_{1}$. Then we get $M B_{1}=0$. In league 2 $T_{2}=\hat{T}-T_{1}$ talents will play. Inserting this into the definition of $M B_{2}$ we find that $M B_{2}>0$ if and only if $(2-\alpha \hat{T}) \log \sigma-2>0$. Given our choice of parameters this condition will always be fulfilled. So, the market demand by the big league implies that in market equilibrium it will hold that $M B_{1}<M B_{2}$. In other words, the free market for talented players generates a situation where too many talents are playing in the big league. 
On the other hand, consider the case where a corner solution occurs, or, league 1 will demand all the talents in the market, $T_{1}=1$. We know that league 1 will demand all the talents if $\alpha=0.1$ and $\alpha=0.3$ and if $\alpha=0.5$ for $\sigma=11$ and $\sigma=15$. Given that $T_{1}=1$ and $T_{2}=0$, we can derive from the definitions of $M B_{1}$ and $M B_{2}$, given in condition (2), that $M B_{1}>M B_{2}$ will hold if $N_{1} / N_{2}>(\log \sigma-1) /(\log \sigma-1 /(1-\alpha)$. In other words, if this inequality holds, the number of talents playing in league 2 is always too high from a social welfare point of view. If it were possible to increase team size and if additional talents came available, it would be optimal to have them migrating to league 1 . It is easy to check that the inequality will hold if $N_{1} / N_{2}>2$. However, if $N_{1} / N_{2}=2$, the inequality will not hold for $\alpha=0.5$ if $\sigma=11$ and $\sigma=15$.

Panels B through D of Table 1 illustrate the above derived conditions. These panels produce the optimal allocation of players as a function of the key parameters. If the market demand for talents is high ( $\alpha=0.1$ or $\alpha=0.3$ ), so that the market locates all the talents in the big league, the market result generates even 'too few' talents in the big league, as we have just seen.. For median demand ( $\alpha=0.5$ ) the market leads to all talents ending up in the big league if the talents' capability is high enough $(\sigma=11,15)$. As we have just seen, this will not lead to an oversupply of talents in the big league, if the big league has more than two times the small league's market size. This is intuitively clear. If the big league is relatively large, it is more efficient to locate the talents in the big league where, given the public-good nature of football, they produce more value than in the small league.

In the cases where the market generates an oversupply of talents in league 1 , the oversupply is larger, for a given value of $\alpha$, if the difference between the market sizes in the leagues, measured by $N_{1} / N_{2}$, is smaller. Moreover, the oversupply of talents in league 1 increases with players' capability, measured by the parameter $\sigma$. Note, however, that for larger relative size of the big league and larger players' capability more talents should be located in the big league. 


\subsection{The social optimum: the efficient allocation of players with lump-sum redistribution}

If talents are allocated in the most efficient way, i.e., condition (2) holds, they will play in the leagues where they generate the largest marginal profit. Obviously, this generates a higher total welfare than the total welfare the market generates. If, however, lump-sum redistributions are feasible between leagues, considerations of equity can play a larger role in the allocation of talents. In particular, as can easily be derived, in this case the profit per capita will be equalized by the FFI. Panel E shows the allocation of talents and the total social welfare without $\left(S W^{N T}\right)$ and with $\left(S W^{L T}\right)$ lump-sum redistributions, respectively. By allowing lump-sum redistributions social welfare increases above the level when only talents are allocated. Interestingly, by showing more consideration for the equity aspects, leading to transfers from the big league to the small league, more talents can be allocated to the big league, compare the number of players, $T_{1}$, in Panels $\mathrm{D}$ and $\mathrm{E}$, respectively. As a result, the market equilibrium and the social welfare optimum will coincide in a larger number of cases (compare Panels A and E), but for the cases where an interior solution occurs, the market still implies an oversupply of talents in the big league.

\subsection{Correcting the market allocation by transfer fees}

Most football associations in the world are not able (or may be even not willing) to locate players according to some social-welfare objective. Some regulations of players movement exist, however. In European football stipulations existed as to the minimum number of native players that had to play in each club. Moreover, the transfer fee system that existed prior to the Bosman ruling by the Court of Justice also had the indirect effect of regulating the number of players that were migrating to other leagues. Negotiated transfer fees enabled the small leagues to limit the migration of players from their leagues, or to get compensation for the welfare loss.

Of course, there was no guarantee that the transfer fees implied the optimal allocation. The point of this subsection, however, is that, giving enough information about the parameters of the leagues, the FFI is for each transaction able to determine the transfer rate that maximizes social welfare. 
Let us again indicate the number of home-grown talents in league $i$ by $\hat{T}_{i}(i=1,2)$ and the number of players that move from the small league to the big league by $T_{21}$. Assume that for each migrated player the big league pays a transfer fee equal to $\tau$ times the wage paid to the talent. Then for the two leagues total profit can be written as:

$$
\Pi_{1}=Y_{1}\left(1-\alpha\left(\hat{T}_{1}+(1+\tau) T_{21}\right)\right), \Pi_{2}=Y_{2}\left(1-\alpha\left(\hat{T}_{2}-T_{21}\right)\right)+\tau \alpha Y_{1} T_{21}
$$

As before, all players that are in demand by the big league, will be migrating from the small league. The first-order condition for the demand for players by the big league, i.e. $T_{21}$, assuming an interior solution equals:

$$
T_{21}=\left(1-(1+\tau) / \log \sigma-\alpha \hat{T}_{1}\right) /(\alpha+\alpha \tau)
$$

As expected the number of home grown talents and the size of the transfer fee have a negative effect on the demand for foreign talents.

Given the market solution that is generated by eq. (4) and the definitions of total profit for the two leagues in eq. (3), the FFI can calculate the tax rate that maximizes the socialwelfare function (1). Although this is a straightforward exercise we get a highly nonlinear solution for the optimal transfer rate. Here, we only present the first-order derivative of the social-welfare function, evaluated in $\tau=0$. Under the condition that $\hat{T}_{1}+\hat{T}_{1}=1$, we get,

$$
\frac{\partial W}{\partial \tau}(\tau=0)=\alpha\left(N_{1}-N_{2}\right) T_{21}^{\prime} \log \sigma+N_{1}+\alpha N_{2} \frac{T_{21}^{\prime}}{1-\alpha\left(\hat{T}_{2}-T_{21}\right)}+\alpha N_{2} \frac{T_{21} Y_{1} / Y_{2}}{1-\alpha\left(\hat{T}_{2}-T_{21}\right)}
$$

where $T_{21}^{\prime}=\partial T_{21} / \partial \tau<0$. Eq. (5) specifies the rationales for the implementation of a transfer fee system. The first term indicates the loss of production value in league 1 relative to the gain in league 2 . The second term represents the savings in wage payments by league 1 that result from the lower demand for foreign talents. The third term represents the additional wage payments by the small league due to the lower emigration of talents, while the last term gives the gain in welfare for league 2 due to the transfer payments that go along with the introduction of a transfer fee system. 
For all combinations of parameters that are used in Table 1 it holds that $\partial W / \partial \tau>0$ in $\tau=0$. So, in all cases total welfare increases if transfer fees are used to compensate the small league for the emigration of their talents. This is even the case if it is optimal to have all the talents playing in the big league.

Table 2. Transfer fees, the demand for foreign talents and social welfare ${ }^{*}$

\begin{tabular}{|c|c|c|c|c|c|c|c|c|c|c|}
\hline & \multicolumn{2}{|c|}{$\alpha=0.1$} & \multicolumn{2}{|c|}{$\alpha=0.3$} & \multicolumn{2}{|c|}{$\alpha=0.5$} & \multicolumn{2}{|c|}{$\alpha=0.7$} & \multicolumn{2}{|c|}{$\alpha=0.9$} \\
\hline & $T_{21}$ & $S W$ & $T_{21}$ & $S W$ & $T_{21}$ & $S W$ & $T_{21}$ & $S W$ & $T_{21}$ & $S W$ \\
\hline$\tau=0.00$ & 0.50 & 665.0 & 0.50 & 678.8 & 0.47 & 684.8 & 0.19 & 692.9 & 0.04 & 697.7 \\
\hline$\tau=0.05$ & 0.50 & 665.1 & 0.50 & 679.1 & 0.40 & 686.6 & 0.15 & 693.8 & 0.01 & 697.8 \\
\hline$\tau=0.10$ & 0.50 & 665.1 & 0.50 & 679.3 & 0.34 & 687.5 & 0.11 & 694.2 & 0.00 & 697.8 \\
\hline$\tau=0.15$ & 0.50 & 665.1 & 0.50 & 679.4 & 0.28 & 687.9 & 0.07 & 694.3 & 0.00 & 697.8 \\
\hline$\tau=0.20$ & 0.50 & 665.1 & 0.50 & 679.6 & 0.22 & 687.9 & 0.04 & 694.1 & 0.00 & 697.8 \\
\hline$\tau=0.25$ & 0.50 & 665.1 & 0.47 & 679.6 & 0.17 & 687.7 & 0.01 & 693.8 & 0.00 & 697.8 \\
\hline$\tau=0.30$ & 0.50 & 665.2 & 0.39 & 679.5 & 0.13 & 687.4 & 0.00 & 693.7 & 0.00 & 697.8 \\
\hline$\tau=0.35$ & 0.50 & 665.2 & 0.31 & 679.0 & 0.08 & 687.0 & 0.00 & 693.7 & 0.00 & 697.8 \\
\hline$\tau=0.40$ & 0.50 & 665.2 & 0.24 & 678.5 & 0.04 & 686.6 & 0.00 & 693.7 & 0.00 & 697.8 \\
\hline$\tau=0.45$ & 0.50 & 665.2 & 0.18 & 677.9 & 0.01 & 685.9 & 0.00 & 693.7 & 0.00 & 697.8 \\
\hline$\tau=0.50$ & 0.50 & 665.2 & 0.12 & 677.4 & 0.00 & 685.9 & 0.00 & 693.7 & 0.00 & 697.8 \\
\hline$\tau=0.55$ & 0.50 & 665.2 & 0.06 & 676.8 & 0.00 & 685.9 & 0.00 & 693.7 & 0.00 & 697.8 \\
\hline$\tau=0.60$ & 0.50 & 665.2 & 0.00 & 676.2 & 0.00 & 685.9 & 0.00 & 693.7 & 0.00 & 697.8 \\
\hline
\end{tabular}

${ }^{*}$ The value of the parameters used for this calculation are: $\sigma=7, N_{1}=100, N_{2}=50, \hat{\mathrm{T}}_{1}=0.5, \hat{\mathrm{T}}_{2}=0.5$.

In Table 2, the effect of one of the key parameters of the model, i.e., $\alpha$ the parameter decisive for the demand for exogenous talents by the football industry, on the optimal transfer rate is displayed. In this example talents are scarce (i.e. $\hat{T}_{1}=0.5$ and $\hat{T}_{2}=0.5$ ), and their capability is relatively low ( $\sigma=7$ ). The big league's market size is twice the small league's size, i.e., $N_{1}=100$ and $N_{2}=50$. If, for this case, the demand for talents is high ( $\alpha=0.1$ and $\alpha=0.3$ ) the big league is eager to import all the talents from the small league as long as no transfer fee system exists. As it appears, whatever the transfer fee rate actually is, the small league is left with no talents for $\alpha=0.1$. The same holds for $\alpha=0.3$ if the transfer fee rate is not set too high. In these cases the transfer fee system merely functions as a lump-sum mechanism to equalize the profit per capita, and the optimal welfare according to Panel E of Table 1 is reached. When the demand for talents diminishes ( $\alpha=0.5$ and higher), the incentive for the big league to import talents does 
depend on the size of the compensating transfer fee rate. From the table it can be seen that the transfer fee rate can be set in such a way that both the optimal allocation of talents and the optimal welfare can be reached.

We conclude that the transfer fee rate should be a positive function of the demand for talents, or, in other words a negative function of $\alpha$. For the other key parameters of the model, i.e., the relative size of the market $\left(N_{1} / N_{2}\right)$ and players' capability $(\sigma)$ the result of analogous calculations as in Table 2 are summarized in Table A1 in the Appendix. With a given talent size $\sigma$, the smaller the receiving country is, the lower the Paretoefficient number of talents is in that country, and so, the lower the optimal transfer fee rate should be. Moreover, a higher capability implies that a migrating player imposes a relatively large loss on his home country, and, therefore, a relatively large transfer is needed to compensate the small league.

Note from the Appendix that buying all the talents from the small league does not have to imply large transfer rates for the big league. In particular, for this case of complete migration the rates $\tau$ range from $6 \%$ of the wage sum $\left(N_{1} / N_{2}=10, \alpha=0.5, \sigma=9\right)$ to $80 \%$ of the wage sum $\left(N_{1} / N_{2}=2, \alpha=0.1, \sigma=12\right)$. If the market sizes of the two leagues are about equal, and when, furthermore, highly capable talents (large $\sigma$ ) are in high demand (low $\alpha$ ), migration of players to the big league should go along with substantial transfer payments in return. But, if the leagues are substantially different in size, demand and players’ capability are low, transfer fee rates should be low.

\section{Migration with endogenous talents}

In this section we assume that both leagues have the opportunity to train individuals to become talented players. To model this the product is assumed to be generated as follows:

$$
Y_{1}=N_{1} \sigma^{\alpha\left(T_{1}+T_{21}\right)} \quad Y_{2}=N_{2} \sigma^{\alpha\left(T_{2}-T_{21}\right)}
$$

and:

$$
T_{i}=\hat{T}_{i}+\delta \log e_{i} \quad(i=1,2)
$$


where $\hat{T}_{i}$ represents the exogenous part of talent availability and $e_{i} \geq 1$ indicates the investment in home talent. An investment equal to $e_{i} \geq 1$ involves costs equal to $c\left(e_{i}-1\right)$. For simplicity we assume that training only determines the number of talents, but their capability remains exogenously given.

Below, we first derive how the social welfare optimum looks like in a closed and an open economy, respectively. Then we compare the market equilibrium, respectively, without and with a transfer fee system, to the social-welfare optimum. Finally, we consider whether a home-grown rule is better able to approach the social-welfare optimum than a transfer fee system.

\subsection{Optimal allocation}

Given this set up, we first consider the case where the FFI is able to determine the command optimum. It sets the optimal amount of training by the leagues, determines the optimal allocation of players to the two leagues, and decides how the revenues from the football product and the costs of the training facilities are shared between the leagues. So, the FFI sets $T_{i}^{*}$ and $e_{i}^{*}$ under the restriction $T_{1}^{*}+T_{2}^{*}=T_{1}+T_{2}$. Moreover, product revenue and training cost sharing is implicitly given shape in the form of a redistributive scheme between the leagues. This scheme contains a transfer $\Gamma$, which can be positive or negative, from the big league to the small league. The FFI maximizes the following social welfare function:

$$
W=N_{1} \log \left(Y_{1}\left(1-\alpha T_{1}\right)-c\left(e_{1}-1\right)-\Gamma\right)+N_{2} \log \left(Y_{2}\left(1-\alpha T_{2}\right)-c\left(e_{2}-1\right)+\Gamma\right)(8)
$$

The first-order conditions read:

$$
\begin{aligned}
& \frac{\Pi_{1}}{N_{1}}=\frac{\Pi_{2}}{N_{2}} \\
& e_{1}^{*}=e_{2}^{*} \\
& Y_{1}\left(\left(1-\alpha T_{1}^{*}\right) \log \sigma-1\right) \geq Y_{2}\left(\left(1-\alpha T_{2}^{*}\right) \log \sigma-1\right)
\end{aligned}
$$


where $\Pi_{1}=Y_{1}\left(1-\alpha T_{1}^{*}\right)-c\left(e_{1}^{*}-1\right)-\Gamma$ is defined as total profit for league 1 , and $\Pi_{2}$ is defined accordingly. Eq. (9) reproduces the well-known fiscal-federalism result that transfers should be such that the profit per capita is equalized. According to eq. (10) both leagues should invest the same amount in training facilities; in other words the total number of talents should be trained such that total training costs are minimized. Eq. (11), finally, governs the optimal allocation of talents. Talents should be located firstly in the league with the large potential. Dependent on the parameters of the model, the marginal loss of moving a player trained in the small league can in equilibrium be smaller than the gain of this move for the big league, in which case the >-sign holds in eq. (11). In this corner solution all talents will be located in the big league while part of their training takes place in the small league.

Note that it is optimal that the two leagues have training facilities even if talents will never play in the small league. As we shall see below, this is typically not one of the properties of the equilibrium generated by the market.

\subsubsection{The optimum in a closed league}

Before proceeding it is of interest to consider how the optimum looks like in a closed league. Welfare maximization then obviously coincides with profit maximization in the closed league. The first-order condition for optimal training reads,

$$
\alpha \delta Y(\log \sigma(1-\alpha T)-1) / e=c
$$

Training talents will be extended until the marginal profits generated by the training of talents equal the marginal training costs.

By totally differentiating first-order condition (12) it follows that the relationship between investment in players and the parameters of the model is nonlinear. Table 3 , that gives the optimum investment in players, and the corresponding number of players, demonstrates this. The market sizes considered are $N=100$ and $N=50$, respectively.

The optimal investment in training players first increases with $\alpha$ and then decreases. It is clear that market size is an important determinant of the investment in talents. Large markets have more incentives to train players than small markets as, team size being identical in the two leagues, the training costs per capita are lower in the big than in the 
small league. As a result, for $\alpha=0.1$ the small league will not find it advantageous to train talents, while the big league still invests in training talents.

Table 3. Investment in players in a closed league*)

\begin{tabular}{|c|c|c|c|c|c|c|c|c|c|c|c|c|c|c|c|}
\hline & \multicolumn{3}{|c|}{$\alpha=0.1$} & \multicolumn{3}{|c|}{$\alpha=0.3$} & \multicolumn{3}{|c|}{$\alpha=0.5$} & \multicolumn{3}{|c|}{$\alpha=0.7$} & \multicolumn{3}{|c|}{$\alpha=0.9$} \\
\hline$N=100$ & $e$ & $T$ & $W$ & $e$ & $T$ & $W$ & $e$ & $T$ & $W$ & $e$ & $T$ & $W$ & $e$ & $T$ & $W$ \\
\hline$\sigma=7$ & 1.42 & 0.10 & 460.7 & 4.03 & 0.42 & 465.9 & 5.52 & 20.51 & 473.1 & 5.39 & 0.51 & 478.6 & 4.53 & 0.45 & 481.9 \\
\hline$\sigma=11$ & 2.13 & 0.23 & 461.4 & 6.70 & 0.57 & 473.2 & 9.83 & 30.69 & 488.2 & 9.11 & 0.66 & 498.9 & 6.91 & 0.58 & 504.5 \\
\hline$\sigma=15$ & 2.64 & 0.29 & 462.3 & 9.01 & 0.66 & 479.6 & 13.95 & 50.79 & 501.4 & 12.30 & 00.75 & 516.2 & 8.63 & 0.65 & 523.0 \\
\hline$N=50$ & $e$ & $T$ & $W$ & $e$ & $T$ & $W$ & $e$ & $T$ & $W$ & $e$ & $T$ & $W$ & $e$ & $T$ & W \\
\hline$\sigma=7$ & 1.00 & 0.00 & 195.6 & 2.09 & 0.22 & 196.5 & 3.19 & 0.35 & 199.0 & 3.69 & 0.39 & 201.7 & 3.60 & 0.38 & 203.8 \\
\hline$\sigma=11$ & 1.05 & 0.01 & 195.6 & 3.32 & 0.36 & 198.7 & 5.44 & 0.51 & 204.5 & 6.27 & 0.55 & 210.2 & 5.68 & 0.52 & 214.1 \\
\hline$\sigma=15$ & 1.29 & 0.08 & 195.7 & 4.35 & 0.44 & 200.7 & 7.56 & 0.61 & 209.6 & 8.63 & 0.65 & 217.8 & 7.32 & 0.60 & 223.0 \\
\hline
\end{tabular}

${ }^{*}$ The value of the parameters used for this calculation are: $\hat{T}=0, \delta=0.3$. $W$ stands for $N_{i} \log \Pi_{i}$.

Increasing capabilities of players gives leagues more incentives to train talented players. Welfare in the leagues, measured by $N_{i} \log \left(\Pi_{i}\right)$, increases with players' capability if investment in talents (e>1) takes place. Moreover, raising talents (e>1) always increase the welfare above the level when only mediocre players are employed $(e=1)$. In the latter case, welfare would equal 460.5 and 195.6 for the big league and the small league, respectively. For all cases considered, however, the number of talented players turns out to be lower than the maximal number.

\subsubsection{The optimum in open leagues}

Table 4 shows for parameter values that we used before how many talents should be trained (indicated by $T_{1}^{*}+T_{2}^{*}$ in the table) and how the talents should be allocated across the leagues (indicated by $T_{i}^{*}$ in the table), according to first-order conditions (9)-(11).

Just as when talents are exogenously given, talents should play only in the big league when $\alpha$ is small. The talents should be raised in both leagues, however, in this case. A transfer from the big league to the small league is enacted, that is very small in absolute terms, but as a percentage of the wage sum it is large: 86 percent of the wage sum of the emigrated players is transferred to the small league, if $\alpha=0.1$ and $o=7$. Nevertheless, total welfare for the small league is only marginally above the welfare the league would receive if it only employed mediocre talents. When for $\alpha=0.1$ capability increases the 
optimal transfer rate increases, even to values above the wage sum that is paid to the emigrated talents who are playing in league 1 . Naturally, when the transferred talents are more capable, the loss for the small league of exporting the talents gets larger and a higher transfer fee rate is required to compensate the small league for the loss of their talents. Moreover, an increase in players’ capability also requires a higher training effort. For all values of $\alpha$ and/or $\sigma$, both leagues stand to gain from the optimal allocation of training facilities and players, compared to the outcome without training and without employing any talents.

Table 4: Optimal investment in talents and allocation of talents ${ }^{*}$

\begin{tabular}{l|cccccccc}
\hline & $T_{1}^{*}$ & $T_{2}^{*}$ & $T_{1}^{*}+T_{2}^{*}$ & $\tau$ & $W_{1}^{*}$ & $W_{2}^{*}$ & $W_{1}^{0}$ & $W_{2}^{0}$ \\
\hline$\alpha=0.1 ; \sigma=7$ & 0.21 & 0.00 & 0.21 & 0.86 & 460.7 & 195.7 & 460.5 & 195.6 \\
$\alpha=0.1 ; \sigma=11$ & 0.46 & 0.00 & 0.46 & 1.14 & 461.8 & 196.2 & 460.5 & 195.6 \\
$\alpha=0.1 ; \sigma=15$ & 0.60 & 0.00 & 0.60 & 1.32 & 463.0 & 196.8 & 460.5 & 195.6 \\
$\alpha=0.5 ; \sigma=7$ & 0.73 & 0.03 & 0.76 & 0.31 & 472.9 & 201.8 & 460.5 & 195.6 \\
$\alpha=0.5 ; \sigma=11$ & 0.99 & 0.01 & 1.00 & 0.31 & 488.6 & 209.7 & 460.5 & 195.6 \\
$\alpha=0.5 ; \sigma=15$ & 1.00 & 0.16 & 1.16 & 0.37 & 502.0 & 216.3 & 460.5 & 195.6 \\
$\alpha=0.9 ; \sigma=7$ & 0.47 & 0.36 & 0.83 & 0.32 & 480.4 & 205.5 & 460.5 & 195.6 \\
$\alpha=0.9 ; \sigma=11$ & 0.59 & 0.51 & 1.10 & 0.39 & 502.3 & 216.5 & 460.5 & 195.6 \\
$\alpha=0.9 ; \sigma=15$ & 0.65 & 0.59 & 1.24 & 0.44 & 520.6 & 225.6 & 460.5 & 195.6
\end{tabular}

${ }^{*}$ The value of the parameters used for this calculation are: $\hat{T}=0, \delta=0.3$. Moreover, $T_{i}^{*}$ indicates the optimal number of talents in $i . W_{i}^{*}$ represents welfare under the social-welfare maximizing solution and $W_{i}^{0}$ is welfare without training facilities and talents for league $i$. The transfer rate $\tau$ is defined by $2 \Gamma /\left(\left(T_{1}^{*}-T_{2}^{*}\right) \alpha Y_{1}\right)$. Finally $N_{1}=100$ and $N_{2}=50$.

\subsection{Market equilibrium}

Let us now consider how the market equilibrium looks like. The big league has the option to train native talents and/or to import talents from the small league. The small league, however, only has the option to train talents.

If transfer fees have to be paid, the big league maximizes the following profit function:

$$
\Pi_{1}=Y_{1}\left(1-\alpha\left(T_{1}+(1+\tau) T_{21}\right)\right)-c\left(e_{1}-1\right)
$$

The first-order conditions for the decision problems read, 


$$
\begin{aligned}
& \frac{\partial \Pi_{1}}{\partial T_{21}}=\alpha Y_{1}\left(\left(1-\alpha T_{1}-\alpha(1+\tau) T_{21}\right) \log \sigma-(1+\tau)\right) \leq 0 \\
& \frac{\partial \Pi_{1}}{\partial e_{1}}=\alpha Y_{1}\left(\left(1-\alpha T_{1}-\alpha(1+\tau) T_{21}\right) \log \sigma-1\right) \delta / e_{1}-c \leq 0
\end{aligned}
$$

\subsubsection{No transfer fee system}

Consider first the case that no transfer fee system exists, so that $\tau=0$ in the first-order conditions (14) and (15). It is then trivial to prove that if the big league wants to import talents, $T_{21}>0$, it will be optimal not to train talents. Hiring players from the small league without the obligation to financially compensate that league thus obviates the need to have an own training system for native talents, and the big league restricts itself to attracting talents from abroad. Unless the demand for foreign players exerted by the big league is relatively small, the small league, on the other hand, will have no incentive to train talents either if it knows that it will lose its talents without being compensated for the emigration of its talents.

In a system without transfers, therefore, the only equilibrium can be one where the small league will have no talents, and the big league will employ home-grown talents only, so that $T_{21}=0$. For the big league this case is therefore identical to the case of a closed league. The results for this case are described in table 3 . The small league can only employ mediocre talents and welfare equals $N_{2} \log N_{2}$.

\subsubsection{A transfer fee system}

Let us now turn to the case with positive transfer rates, $\tau>0$. The small league will have an incentive to train talents if it can derive a positive profit from exporting talents to the big league. Crucially this depends on how the small league perceives the relation between their training efforts and the emigration of talents. We assume here that the small league knows the demand for their talents by the big league, $T_{21}$. If the small league trains a number of talents, then, given the dominant position of the big league on the players' market, the small league knows that the first $T_{21}$ of these home-grown talents will emigrate to the big league, while the remainder can be employed in the small league. Obviously, if the small league chooses not to train talents to satisfy the big league's 
demand, it is not able to train talents for the own league as well. Therefore, a small league will choose to export talents, even at a loss, if the gain from employing talents in the own league is enough to compensate the possible loss from exporting talents.

If the loss associated with training talents for the export is too high to make raising additional talents for the own league worthwhile, then the only option for the small league is not to train talents and employ mediocre talents. For the big league the equilibrium is in that case given by the closed-economy solution, illustrated in Table 3.

Table 5. Market equilibrium for training and transferring talents with transfer fee rates ${ }^{*}$

\begin{tabular}{|c|c|c|c|c|c|c|c|c|c|c|c|c|c|}
\hline \multirow[b]{3}{*}{$\tau=0.1$} & \multicolumn{7}{|c|}{$\alpha=0.5 ; \sigma=7$} & \multicolumn{6}{|c|}{$\alpha=0.9 ; \sigma=7$} \\
\hline & $T_{1}$ & $T_{21}$ & $T_{2}$ & $W_{1}$ & $W_{2}$ & $W$ & $W^{*}$ & $T_{1}$ & $T_{21}$ & $T_{2}$ & $W_{1} \quad W_{2}$ & $W$ & $W^{*}$ \\
\hline & \begin{tabular}{|l|}
0.51 \\
\end{tabular} & 0.00 & 0.00 & 473.1 & 195.6 & 668.7 & 675.7 & 0.34 & 0.13 & 0.32 & 482.5203 .0 & 685.5 & 685.9 \\
\hline$\tau=0.3$ & 0.42 & 0.19 & 0.18 & 474.1 & 199.9 & 674.0 & 675.7 & 0.45 & 0.00 & 0.38 & 481.9203 .8 & 685.7 & 685.9 \\
\hline \multirow[t]{3}{*}{$\tau=0.5$} & 0.51 & 0.00 & 0.35 & 473.1 & 199.0 & 672.2 & 675.7 & 0.45 & 0.00 & 0.38 & 481.9203 .8 & 685.7 & 685.9 \\
\hline & \multicolumn{7}{|c|}{$\alpha=0.5 ; \sigma=11$} & \multicolumn{6}{|c|}{$\alpha=0.9 ; \sigma=11$} \\
\hline & $T_{1}$ & $T_{21}$ & $T_{2}$ & $W_{1}$ & $W_{2}$ & $W$ & $W^{*}$ & $T_{1}$ & $T_{21}$ & $T_{2}$ & $W_{2}$ & $W$ & $W^{*}$ \\
\hline$\tau=0.1$ & 0.69 & 0.00 & 0.00 & 488.2 & 195.6 & 683.8 & 698.3 & 0.47 & 0.12 & 0.47 & 505.1213 .2 & 718.3 & 718.8 \\
\hline$\tau=0.3$ & 0.54 & 0.29 & 0.23 & 491.5 & 205.3 & 696.9 & 698.3 & 0.58 & 0.00 & 0.52 & 504.5214 .1 & 718.6 & 718.8 \\
\hline \multirow[t]{3}{*}{$\tau=0.5$} & 0.65 & 0.06 & 0.45 & 488.4 & 205.6 & 694.0 & 698.3 & 0.58 & 0.00 & 0.52 & 504.5214 .1 & 718.6 & 718.8 \\
\hline & \multicolumn{7}{|c|}{$\alpha=0.5 ; \sigma=15$} & \multicolumn{6}{|c|}{$\alpha=0.9 ; \sigma=15$} \\
\hline & $T_{1}$ & $T_{21}$ & $T_{2}$ & $W_{1}$ & $W_{2}$ & $W$ & $W^{*}$ & $T_{1}$ & $T_{21}$ & $T_{2}$ & $W_{1} \quad W_{2}$ & $W$ & $W^{*}$ \\
\hline$\tau=0.1$ & 0.79 & 0.00 & 0.00 & 501.4 & 195.6 & 697.0 & 718.3 & 0.57 & 0.09 & 0.57 & 523.4222 .5 & 745.9 & 746.2 \\
\hline$\tau=0.3$ & 0.63 & 0.32 & 0.28 & 506.5 & 210.4 & 716.9 & 718.3 & 0.65 & 0.00 & 0.60 & 523.0223 .0 & 746.1 & 746.2 \\
\hline$\tau=0.5$ & 0.74 & 0.10 & 0.51 & 502.1 & 211.6 & 713.7 & 718.3 & 0.65 & 0.00 & 0.60 & 523.0223 .0 & 746.1 & 746.2 \\
\hline
\end{tabular}

${ }^{*}$ The value of the parameters used for this calculation are: $N_{1}=100, N_{2}=50, \hat{T}=0, \delta=0.3 . T_{1}$ is the number of talents trained and playing in league 1. $T_{21}\left(T_{2}\right)$ is the number of players trained in league 2 and playing in league 1 (2). $W_{i}$ stands for $N_{i} \log \Pi_{i}$. and $W=W_{1}+W_{2} \cdot W^{*}=W_{1}^{*}+W_{2}^{*}$ can be found in table 4 . For $\alpha=0.1$ the equilibrium is the closed-league solution for league 1 and $e_{2}=0$ for the small league in all cases.

The procedure for calculating the equilibrium is as follows. In the first stage the big leagues determines their optimal training efforts and their demand for talents from abroad by means of eqs. (14) and (15). The small league takes the demand for their talents $T_{21}$ as given and maximizes its profit function which reads:

$$
\Pi_{2}=Y_{2}\left(1-\alpha\left(T_{2}-T_{21}\right)\right)+\tau \alpha Y_{1} T_{21}
$$


The small league only decides on its training efforts, $e_{2}$, generating, say, $T_{2}\left(e_{2}\right)$ talents. If $T_{2}\left(e_{2}\right)>T_{21}$ part of the trained talents can be employed in the own league. On the other hand, if $T_{2}\left(e_{2}\right)<T_{21}$ not enough talents are raised to satisfy the big league's demand. League 1 then has to recalculate its optimal own training efforts, while given the lower number of talents the small league will have to supply, the small league should reoptimize as well. The outcome of the latter calculation can result in higher investment in talents by the small league than in the first-round calculation. However, the big league will be motivated to reconsider its demand for foreign talents once again, as the supply of talents in the small league turns out to be larger. This iterative process does not necessarily lead to equilibrium. In that case, the only feasible equilibrium is where the big league is like a closed league and the small league only employs mediocre talents.

For some of the specific parameter values that we employed the market equilibrium is shown in Table 5. In the cases where $\alpha=0.5$ and the transfer rate equals $\tau=0.1$, the above described procedure did not result in a consistent equilibrium. By assumption the closed-economy annex mediocre talents case arises. The no-talent case for league 2 implies a welfare equal to 195.6.

In all other cases shown in the table some export of talents takes place, or no foreign talents are demanded at all. In those cases the welfare for league 2 is considerably above the welfare that would be obtained when league 1 is not able to satisfy its demand for foreign talents.

Not surprisingly, the market always produces a lower welfare than the corresponding social optimum in Table 5. More interestingly, in the market equilibrium with positive transfer fees the small league will employ more talents in their own competition than in the social optimum. The reason is that the transfer rate in the market has a substitution effect that makes the demand for foreign talents by league 1 move away from the optimal amount and makes it instead more advantageous to train their own talents. In the social optimum the transfer fee system is of a lump-sum nature. As a result, by introducing a transfer fee system for emigrating players the transfer fee rate that maximizes welfare $W$ will generally be lower than the optimal transfer fee rate that maximizes social welfare $W^{*}$. This is most clear for $\alpha=0.9$. According to Table 4 the optimal transfer fee rate in 
the social optimum would be between 0.32 and 0.44 . For such a rate in the market, however, the big league would not demand any talent from the small league at all as is shown in the right-hand panels of Table 6. For both leagues 1 and 2 the closed-economy case will result, which is advantageous to the small league compared to the case with no training facilities. For league 2 the social welfare optimum would imply higher welfare, however.

\subsubsection{A home-grown players rule}

As mentioned in the introduction an alternative way to regulate the mobility of players is by introducing a 'nationality' rule or a 'home-grown' rule. The former rule has been deemed conflicting with European laws as it imposes an impediment to the free movement of persons. The latter rule, however, as it is now applied in European Football is not based on nationality and thus will probably not be interpreted as an infringement on European law. The purpose of this subsection is to consider the effectiveness of this rule in reaching the social-welfare solution and to compare it to a system of transfer fees, considered previously.

In our model, the home-grown rule will only be effective for league 1 as league 2 has no other option but to employ home-grown talents, or no talents at all. Indicate the total number of talented players in league 1 by $T^{1}=T_{1}+T_{21}$, where as before $T_{1}$ is the number of home-grown talents and $T_{21}$ is the number of talents transferred from the small league. A home-grown rule prescribes that $T_{1}$ should at least be a proportion, say $\lambda$, of the total number of talents playing in league 1 . League 1 can decide to train more talents than prescribed. This is indicated by the parameter $\mu$, so that the total number of home-grown talents playing in the big league equals $T_{1}=(\lambda+\mu) T^{1}$, where $\mu \geq 0$. It follows that the relationship between home-grown and imported talents can be written as $T_{1}=\varepsilon T_{21}$, where $\varepsilon=(\lambda+\mu) /(1-\lambda-\mu)$. With these definitions, and assuming no transfer fee system, profits for league 1 can be written as:

$$
\left.\Pi_{1}=N_{1} \sigma^{\alpha(1+\varepsilon) T_{21}}\left(1-\alpha(1+\varepsilon) T_{21}\right)\right)-c\left(e_{1}-1\right)
$$


Profits are maximized with respect to the number of additional home-grown talents, represented by the parameter $\mu$, and the number of talents hired from abroad, $T_{21}$. The first-order conditions for the decision problem read;

$$
\begin{aligned}
& \frac{\partial \Pi_{1}}{\partial T_{21}}=\alpha Y_{1}\left(\left(1-\alpha(1+\varepsilon) T_{21}\right) \log \sigma-1\right) \leq 0 \\
& \frac{\partial \Pi_{1}}{\partial \mu}=\alpha Y_{1}\left(\left(1-\alpha(1+\varepsilon) T_{21}\right) \log \sigma-1\right) \delta / e_{1}-c \leq 0
\end{aligned}
$$

It is easy to see from these first-order conditions that if an interior solution for the number of imported talents hold, $T_{21}>0$, no additional talents will be raised at home, i.e. $\mu=0$. The optimal import of talents can then easily be derived from (18) as:

$$
T_{21}=\left(1-\frac{1}{\log \sigma}\right) \frac{1}{\alpha(1+\varepsilon)}
$$

Table 6. Home-grown rule, players' allocation and welfare*)

\begin{tabular}{l|lllllll}
\hline & $\lambda$ & $T_{1}$ & $T_{21}$ & $T_{2}$ & $W^{h g}$ & $W^{t r}$ & $W^{*}$ \\
\hline$\alpha=0.5 ; \sigma=7$ & 0.86 & 0.84 & 0.14 & 0.23 & 658.8 & 674.0 & 674.7 \\
$\alpha=0.5 ; \sigma=11$ & 0.83 & 0.83 & 0.17 & 0.35 & 690.2 & 696.9 & 698.3 \\
$\alpha=0.5 ; \sigma=15$ & 0.81 & 0.81 & 0.19 & 0.42 & 712.8 & 716.9 & 718.3 \\
$\alpha=0.9 ; \sigma=7$ & 0.65 & 0.35 & 0.19 & 0.29 & 684.1 & 685.7 & 685.7 \\
$\alpha=0.9 ; \sigma=11$ & 0.68 & 0.44 & 0.21 & 0.42 & 715.8 & 718.6 & 718.8 \\
$\alpha=0.9 ; \sigma=15$ & 0.70 & 0.49 & 0.21 & 0.51 & 742.6 & 746.1 & 746.2 \\
\hline
\end{tabular}

${ }^{*}$ The value of the parameters used for this calculation are: $N 1=100, N_{2}=50 . \quad \lambda$ is the minimum homegrown rule for which the small league 2 finds it advantageous to train talents, $T_{1}$ is the number of players trained in country $1, T_{21}\left(T_{2}\right)$ is the number of players trained in league 2 and playing in league 1 (2). $W^{h g}, W^{t r}, W^{*}$ are welfare under the home-grown rule, the transfer-rate system and the social optimum, respectively

What remains to be considered is how high the required home-grown rate $\lambda$ has to be in order to make it advantageous for league 2 to have training facilities of their own. For a too low value of $\lambda$ league 2 will lose 'too many' of its talents and not start training facilities and play with mediocre talented players only. Actually, it turns out with our sample of parameters that if $\alpha=0.1$ league 1's demand for foreign talents for any $\lambda<1$ will be such that the small league will have no incentive to start training their 
talents. The market equilibrium, where the big league produces talents as in the closed league and the small league does not have talents, emerges as a result.

Table 6 gives for a limited number of parameter combinations the home-grown rule and the players' allocation. The table also presents the welfare comparison between the homegrown rule, the transfer fee system and the social-welfare optimum.

What emerges from the table is that the required value of the home-grown rule $\lambda$ has to be very high before becoming effective. At least $65 \%$ of the players have to be home grown in order to make it advantageous for league 2 to have its own training facilities, while, as said before, if $\alpha=0.1$ all talents have to be home grown. What we can also infer from the table is that even if the home-grown rule is effective, i.e. if the rule makes it possible for league 2 to employ talents, the actual obtained total welfare in the leagues is lower than the welfare obtained in the market equilibrium with a transfer fee system.

\subsubsection{Welfare comparisons}

Wrapping up this section we make a welfare comparison between the different analyzed cases in Table 7 for a subset of the considered parameter values.

Table 7: Welfare in the command optimum, the market, transfer fees and a home-grown rule ${ }^{*}$

\begin{tabular}{l|cccccccccccc}
\hline & $W_{1}^{*}$ & $W_{2}^{*}$ & $W^{*}$ & $W_{1}^{n t}$ & $W_{2}^{n t}$ & $W^{n t}$ & $W_{1}^{t}$ & $W_{2}^{t}$ & $W^{t}$ & $W_{1}^{\text {hg }}$ & $W_{2}^{\text {hg }}$ & $W^{\text {hg }}$ \\
\hline$\alpha=0.1 ; \sigma=7$ & 460.7 & 195.7 & 656.4 & 460.7 & 195.6 & 656.3 & 460.7 & 195.6 & 656.3 & 460.7 & 195.6 & 656.3 \\
$\alpha=0.1 ; \sigma=15$ & 463.0 & 196.8 & 659.8 & 462.3 & 195.6 & 657.9 & 462.3 & 195.6 & 657.9 & 462.3 & 195.7 & 658.0 \\
$\alpha=0.5 ; \sigma=7$ & 472.9 & 201.8 & 674.7 & 473.1 & 195.6 & 668.7 & 474.1 & 199.9 & 674.0 & 462.4 & 196.2 & 658.5 \\
$\alpha=0.5 ; \sigma=15$ & 502.0 & 216.3 & 718.3 & 501.4 & 195.6 & 697.0 & 506.5 & 210.4 & 716.9 & 511.1 & 201.7 & 712.8 \\
$\alpha=0.9 ; \sigma=7$ & 480.4 & 205.5 & 685.9 & 481.9 & 195.6 & 677.5 & 481.9 & 203.8 & 685.7 & 485.1 & 199.0 & 684.1 \\
$\alpha=0.9 ; \sigma=15$ & 520.6 & 225.6 & 746.2 & 523.0 & 195.6 & 718.6 & 523.0 & 223.0 & 746.1 & 527.6 & 215.0 & 742.6 \\
\hline
\end{tabular}

${ }^{*} W_{i}^{*}$ represents welfare under the social-welfare maximizing solution $W_{i}^{n t}\left(W_{i}^{t}\right)$ is the market solution without (with) a transfer fee system. $W_{i}^{\text {hg }}$ is the welfare under the home-grown rule. The welfare without training facilities and talents for league $i$.would be 460.5 and 195.6, respectively. Total welfare in this case equals 656.1. Finally $N_{1}=100$ and $N_{2}=50$.

For low $\alpha$ and low $\sigma$, i.e. $\alpha=0.1$ and $\sigma=7$, the social welfare optimum gives a welfare that is only slightly above the welfare under the market equilibrium with or without transfers and the home-grown rule. At the other extreme, consider the case where $\alpha=0.9$ and $\sigma=15$. The social welfare maximum in this case is equal to 746.2 which is 
substantially above the market equilibrium (718.6). A transfer fee system is doing reasonably well in approaching the social-welfare optimum, though. Compared to a system without transfers, transfer fees are, of course, especially beneficial to the small league. However, compared to the social-welfare optimum transfer fee system benefits the big league. In other words, the redistribution, which is necessary to correct the market inefficiency in an unrestricted market, turns out to be too low in a transfer fee system.

The home-grown rule is a rather blunt device for approaching the social-welfare optimum. The effective value of the home-grown rule appears to lead to too low emigration of talents, when emigration should be high (low $\alpha$ and $\sigma$ ), and it leads even to too much emigration when emigration should be low (high $\alpha$ and $\sigma$ ). Take the latter case, i.e., $\alpha=0.9$ and $\sigma=15$. Under the home-grown rule the small league will train their own talents, but those who are allowed to emigrate according to the rule move for free to the big league. League 1 is by rule forced to have its own training facilities. However, compared to both a transfer fee system and the command optimum, they will train less own talents and import more talents from the small league. As a result, in this case the big league will benefit from the home-grown rule, compared to the command optimum and a transfer fee system

So, compared to the social optimum, the market generates large losses when especially $\alpha$ is large and talent capability is high. A home-grown rule is not a suitable correction device, but a transfer fee system is, although, compared to the social optimum, the compensation for the small league is too small.

\section{Conclusion}

In a common football market with mobile players, like the European football market actually is, a free-market equilibrium will only under very special circumstances be efficient. How large the efficiency loss in equilibrium actually will be depends, among other things, on the relative market sizes of the leagues. Market size is modeled here as a positive function of population size. In European football this seems a reasonable approximation. The 'big' football leagues in Europe, like the Premier League in England and the Primera Division in Spain, serve a much larger potential crowd than smaller 
leagues like those of the Netherlands and the Scandinavian countries. These big leagues, therefore, have larger income sources from ticket sales and broadcast revenues, and are able to pay higher salaries to their top players than the small leagues. Eventually, the top players in these small leagues will be drawn away to play in the top leagues. In fact, this is the basic assumption that we made in the model with exogenous talent availability, i.e. that top leagues are always able to satisfy their demand for talents from abroad. For this case, it is easy to demonstrate that a system of transfer fees as compensation for migrating players can help to remedy the suboptimal supply of talents in the big league.

For the case where talents have to be trained, transfer fees also can help to remedy the inefficiency of the market. Without any transfer fees the small league will easily lose its incentive to train talents, and the resulting equilibrium will be one where there is no migration and undersupply of talents occurs. A system of transfer fees restores the incentive to install training facilities for the talents in the small league. However, the number of talents that will be raised can be too large. As the transfer rate to be paid by the big league decreases demand for foreign talents, the small league will have to export less talents and can, therefore, employ more and in fact too many talents in their home league. This inefficiency, engendered by the transfer fee system, however, is smaller than the inefficiency that the free market without transfer fees produce.

The home-grown rule that prescribes that a certain proportion of the roster of players should be 'home-grown' does not appear to be very effective in reaching the socialwelfare optimum. The reason for its ineffectiveness is that the proportion of home-grown players should be unrealistically high. For a too low proportion the small league will not find it worthwhile to train its own talents and an equilibrium will result where only the big league has training facilities. But, if the home-grown rule is effective, it always lead to inefficient migration flows. In particular, if migration should be low from a normative point of view, the home grown rule produces too much migration, and, the other way round if migration should be high. Note that the European Parliament in a recent resolution suggested that the home-grown rule should be supported by the European Commission as a means to restore competitive balance. This paper shows that this rule can be useful in reaching a more level playing field across leagues. However, this statement is only true if a home-grown rule is compared with a market with free and 
uncompensated migration of talents as the Bosman ruling intended to imply. If the homegrown rule is compared to a system of optimal transfer fees, however, the home-grown rule fares less well: especially when both leagues should have approximately the same number of talents and migration should be low as a result, the home-grown rule leads to too many talents in the big league and a too high level of mobility of talents.

Finally, notice that in some of the analyzed cases it appeared to be optimal that the small league trained talents, but did not employ them. In that case monetary transfers from the big league to the small league had to occur to compensate the small league for the loss of talents. Let us point out, however, that our analysis is based, first, on the assumption that transfer money provides the same utility as the money talents produce by playing in their own country. Second, if the federal football authority was using another social welfare function that gave more weight to the small leagues' welfare, like a Rawlsian function, the welfare loss of losing talents by the small league would be more important, and thus could lead to the result that talents should always play in the small league.

\section{References}

Boadway, R (2004)., The Theory and Practice of Equalization, CESifo Economic Studies, vol. 50, pp.211254.

Boadway R. and F. Flatters (1982), Efficiency and equalization payments in a federal system of government: a synthesis and extension of recent results, Canadian Journal of Economics, vol. 40, pp.613-633.

El-Hodiri, M. and J. Quirk (1971), An economic model of a professional sports league, Journal of Political Economy, vol. 98 (6), pp. 1307-1324.

European Parliament (2007), The future of professional football in Europe, Resolution of 29 March 2007, 2006/2130(INI).

Fees, W. and G. Muehlheusser (2003a), The impact of transfer fees on professional sports: an analysis of the new transfer system for European football, Scandinavian Journal of Economics, vol 105, 139154.

Fees, W. and G. Muehlheusser (2003), Transfer fee regulation in European football, European Economic Review, vol 47, 645-668.

Palomino, F. and J. Sakovics (2004), Inter-league competition for talent vs. competitive balance, International Journal of Industrial Organization, vol. 22, 783-797.

Szymanski, S., (2003): “The economic design of sporting contests”, The Journal of Economic Literature, vol. 41, 1137-1187.

Szymanski, S. and S. Késenne (2004), Competitive balance and gate revenue sharing in team sports, Journal of Industrial Economics, vol. 52, pp. 165-177.

Terviö, M. (2006), Transfer fee regulation and player development, Journal of the European Economics Association, vol. 4, 957-987. 


\section{Appendix}

Table A1. Exogenous talents, optimal transfer fees and the demand for foreign talents ${ }^{*}$

\begin{tabular}{|c|c|c|c|c|c|c|c|c|c|c|c|c|c|c|c|c|c|c|}
\hline & \multicolumn{6}{|c|}{$N_{1} / N_{2}=10$} & \multicolumn{6}{|c|}{$N_{1} / N_{2}=5$} & \multicolumn{6}{|c|}{$N_{1} / N_{2}=2$} \\
\hline & \multicolumn{2}{|c|}{$\alpha=0.1$} & \multicolumn{2}{|c|}{$\alpha=0.5$} & \multicolumn{2}{|c|}{$\alpha=0.9$} & \multicolumn{2}{|c|}{$\alpha=0.1$} & \multicolumn{2}{|c|}{$\alpha=0.5$} & \multicolumn{2}{|c|}{$\alpha=0.9$} & \multicolumn{2}{|c|}{$\alpha=0.1$} & & \multicolumn{2}{|c|}{$\alpha=0.9$} \\
\hline & $T_{21}$ & $\tau$ & $T_{21}$ & $\tau$ & $T_{21}$ & $\tau$ & $T_{21}$ & $\tau$ & $T_{21}$ & $\tau$ & $T_{21}$ & $\tau$ & $T_{21}$ & $\tau$ & & $\tau$ & $T_{21}$ & $\tau$ \\
\hline \multicolumn{19}{|c|}{$\hat{\mathrm{T}}_{1}=0.5, \hat{\mathrm{T}}_{2}=0.5$} \\
\hline$\sigma=7$ & 0.50 & 0.12 & 0.41 & 0.04 & 0.03 & 0.01 & 0.50 & 0.24 & 0.37 & 0.07 & 0.03 & 0.02 & 0.50 & 0.50 & 0 & 0.18 & 0.02 & 0.04 \\
\hline$\sigma=11$ & 0.50 & 0.19 & 0.50 & 0.07 & 0.13 & 0.03 & 0.50 & 0.37 & 0.50 & 0.12 & 0.11 & 0.06 & 0.50 & 0.74 & 0 & 0.19 & 0.07 & 0.15 \\
\hline$\sigma=15$ & 0.50 & 0.25 & 0.50 & 0.09 & 0.18 & 0.04 & 0.50 & 0.45 & 0.50 & 0.16 & 0.16 & 0.07 & 0.50 & 0.91 & 0 & 0.21 & 0.11 & 0.18 \\
\hline \multicolumn{19}{|c|}{$\hat{\mathrm{T}}_{1}=0, \hat{\mathrm{T}}_{2}=1.0$} \\
\hline$\sigma=7$ & 1.00 & 0.06 & 0.93 & 0.02 & 0.54 & 0.00 & 1.00 & 0.12 & 0.90 & 0.04 & 0.53 & 0.01 & 1.00 & 0.25 & 0 & 0.11 & 0.52 & 0.02 \\
\hline$\sigma=11$ & 1.00 & 0.10 & 1.00 & 0.04 & 0.64 & 0.01 & 1.00 & 0.19 & 1.00 & 0.07 & 0.63 & 0.02 & 1.00 & 0.37 & 0 & 0.12 & 0.59 & 0.05 \\
\hline$\sigma=15$ & 1.00 & 0.13 & 1.00 & 0.04 & 0.68 & 0.02 & 1.00 & 0.23 & 1.00 & 0.08 & 0.67 & 0.03 & 1.00 & 0.46 & 1 & 0.15 & 0.64 & 0.06 \\
\hline
\end{tabular}

${ }^{*} N_{1}=100$ is used as the base for the calculations

Table A1 gives the optimal transfer rates for the case of exogenously given talents (section 3). It can be read from the table that the transfer rate should be a negative function of $\alpha$, a negative function of the relative size of the market $\left(N_{1} / N_{2}\right)$ and a positive function of players’ capability $(\sigma)$.

The effect of the availability of talents in both leagues can be seen by comparing the case where the talents are equally distributed among the leagues $\left(\hat{T}_{1}=0.5, \hat{T}_{2}=0.5\right)$ with the case where the small league has all the talents $\left(\hat{T}_{1}=0, \hat{T}_{2}=1\right)$. Again with low $\alpha$ the big league hires all the talents, this time all natives from the small league's country. However, although the big league starts without any talents, the optimal transfer rate in this case is always lower, i.e., approximately half the rate when the talents are equally spread. The total transfer payments to be paid will, therefore be about the same in the two cases. This result implies that from a social welfare perspective the availability of a relatively large exogenous endowment of talent in a small league does not entitle that league to large financial compensations for transferring their talents. 


\section{CESifo Working Paper Series}

(for full list see www.cesifo-group.de)

1940 Monika Bütler and Michel André Maréchal, Framing Effects in Political Decision Making: Evidence from a Natural Voting Experiment, March 2007

1941 Giacomo Corneo and Olivier Jeanne, A Theory of Tolerance, March 2007

1942 Qing Hong and Michael Smart, In Praise of Tax Havens: International Tax Planning and Foreign Direct Investment, March 2007

1943 Yin-Wong Cheung, Dickson Tam and Matthew S. Yiu, Does the Chinese Interest Rate Follow the US Interest Rate?, March 2007

1944 Panu Poutvaara and Mikael Priks, Unemployment and Gang Crime: Could Prosperity Backfire?, March 2007

1945 Burkhard Heer, On the Modeling of the Income Distribution Business Cycle Dynamics, March 2007

1946 Christoph A. Schaltegger and Lars P. Feld, Are Fiscal Adjustments less Successful in Decentralized Governments?, March 2007

1947 Giovanni Facchini, Marcelo Olarreaga, Peri Silva and Gerald Willmann, Substitutability and Protectionism: Latin America's Trade Policy and Imports from China and India, March 2007

1948 C. Mirjam van Praag and Bernard M. S. van Praag, The Benefits of Being Economics Professor A (and not Z), March 2007

1949 Astrid Hopfensitz and Frans van Winden, Dynamic Choice, Independence and Emotions, March 2007

1950 Guglielmo Maria Caporale and Luis A. Gil-Alana, A Multivariate Long-Memory Model with Structural Breaks, March 2007

1951 Mattias Ganslandt and Keith E. Maskus, Wholesale Price Discrimination and Parallel Imports, March 2007

1952 Michela Redoano, Fiscal Interactions Among European Countries. Does the EU Matter?, March 2007

1953 Stefan C. Wolter, Rémy Hübschi and Matthias Müller, Push or Pull? An Empirical Analysis of the Demand for Individual Project Grants from the Swiss National Science Foundation, March 2007 
1954 Scott Alan Carson, African-American and White Inequality in the American South: Evidence from the $19^{\text {th }}$ Century Missouri State Prison, March 2007

1955 Peter Egger, Marko Koethenbuerger and Michael Smart, Do Fiscal Transfers Alleviate Business Tax Competition? Evidence from Germany, March 2007

1956 Panu Poutvaara and Lars-H. R. Siemers, Smoking and Social Interaction, March 2007

1957 Stephan Danninger and Fred Joutz, What Explains Germany's Rebounding Export Market Share?, March 2007

1958 Stefan Krasa and Mattias Polborn, Majority-efficiency and Competition-efficiency in a Binary Policy Model, March 2007

1959 Thiess Buettner and Georg Wamser, Intercompany Loans and Profit Shifting Evidence from Company-Level Data, March 2007

1960 Per Pettersson-Lidbom and Mikael Priks, Behavior under Social Pressure: Empty Italian Stadiums and Referee Bias, April 2007

1961 Balázs Égert and Carol S. Leonard, Dutch Disease Scare in Kazakhstan: Is it real?, April 2007

1962 Paul De Grauwe and Pablo Rovira Kaltwasser, Modeling Optimism and Pessimism in the Foreign Exchange Market, April 2007

1963 Volker Grossmann and Thomas M. Steger, Anti-Competitive Conduct, In-House R\&D, and Growth, April 2007

1964 Steven Brakman and Charles van Marrewijk, It's a Big World After All, April 2007

1965 Mauro Ghinamo, Paolo M. Panteghini and Federico Revelli, FDI Determination and Corporate Tax Competition in a Volatile World, April 2007

1966 Inés Macho-Stadler and David Pérez-Castrillo, Optimal Monitoring to Implement Clean Technologies when Pollution is Random, April 2007

1967 Thomas Eichner and Ruediger Pethig, Efficient $\mathrm{CO}_{2}$ Emissions Control with National Emissions Taxes and International Emissions Trading, April 2007

1968 Michela Redoano, Does Centralization Affect the Number and Size of Lobbies?, April 2007

1969 Christian Gollier, Intergenerational Risk-Sharing and Risk-Taking of a Pension Fund, April 2007

1970 Swapan K. Bhattacharya and Biswa N. Bhattacharyay, Gains and Losses of India-China Trade Cooperation - a Gravity Model Impact Analysis, April 2007

1971 Gerhard Illing, Financial Stability and Monetary Policy - A Framework, April 2007 
1972 Rainald Borck and Matthias Wrede, Commuting Subsidies with two Transport Modes, April 2007

1973 Frederick van der Ploeg, Prudent Budgetary Policy: Political Economy of Precautionary Taxation, April 2007

1974 Ben J. Heijdra and Ward E. Romp, Retirement, Pensions, and Ageing, April 2007

1975 Scott Alan Carson, Health during Industrialization: Evidence from the $19^{\text {th }}$ Century Pennsylvania State Prison System, April 2007

1976 Andreas Haufler and Ian Wooton, Competition for Firms in an Oligopolistic Industry: Do Firms or Countries Have to Pay?, April 2007

1977 Eckhard Janeba, Exports, Unemployment and the Welfare State, April 2007

1978 Gernot Doppelhofer and Melvyn Weeks, Jointness of Growth Determinants, April 2007

1979 Edith Sand and Assaf Razin, The Role of Immigration in Sustaining the Social Security System: A Political Economy Approach, April 2007

1980 Marco Pagano and Giovanni Immordino, Optimal Regulation of Auditing, May 2007

1981 Ludger Woessmann, Fundamental Determinants of School Efficiency and Equity: German States as a Microcosm for OECD Countries, May 2007

1982 Bas Jacobs, Real Options and Human Capital Investment, May 2007

1983 Steinar Holden and Fredrik Wulfsberg, Are Real Wages Rigid Downwards?, May 2007

1984 Cheng Hsiao, M. Hashem Pesaran and Andreas Pick, Diagnostic Tests of Cross Section Independence for Nonlinear Panel Data Models, May 2007

1985 Luis Otávio Façanha and Marcelo Resende, Hierarchical Structure in Brazilian Industrial Firms: An Econometric Study, May 2007

1986 Ondřej Schneider, The EU Budget Dispute - A Blessing in Disguise?, May2007

1987 Sascha O. Becker and Ludger Woessmann, Was Weber Wrong? A Human Capital Theory of Protestant Economic History, May 2007

1988 Erkki Koskela and Rune Stenbacka, Equilibrium Unemployment with Outsourcing and Wage Solidarity under Labour Market Imperfections, May 2007

1989 Guglielmo Maria Caporale, Juncal Cunado and Luis A. Gil-Alana, Deterministic versus Stochastic Seasonal Fractional Integration and Structural Breaks, May 2007

1990 Cláudia Costa Storti and Paul De Grauwe, Globalization and the Price Decline of Illicit Drugs, May 2007 
1991 Thomas Eichner and Ruediger Pethig, Pricing the Ecosystem and Taxing Ecosystem Services: A General Equilibrium Approach, May 2007

1992 Wladimir Raymond, Pierre Mohnen, Franz Palm and Sybrand Schim van der Loeff, The Behavior of the Maximum Likelihood Estimator of Dynamic Panel Data Sample Selection Models, May 2007

1993 Fahad Khalil, Jacques Lawarrée and Sungho Yun, Bribery vs. Extortion: Allowing the Lesser of two Evils, May 2007

1994 Thorvaldur Gylfason, The International Economics of Natural Resources and Growth, May 2007

1995 Catherine Roux and Thomas von Ungern-Sternberg, Leniency Programs in a Multimarket Setting: Amnesty Plus and Penalty Plus, May 2007

1996 J. Atsu Amegashie, Bazoumana Ouattara and Eric Strobl, Moral Hazard and the Composition of Transfers: Theory with an Application to Foreign Aid, May 2007

1997 Wolfgang Buchholz and Wolfgang Peters, Equal Sacrifice and Fair Burden Sharing in a Public Goods Economy, May 2007

1998 Robert S. Chirinko and Debdulal Mallick, The Fisher/Cobb-Douglas Paradox, Factor Shares, and Cointegration, May 2007

1999 Petra M. Geraats, Political Pressures and Monetary Mystique, May 2007

2000 Hartmut Egger and Udo Kreickemeier, Firm Heterogeneity and the Labour Market Effects of Trade Liberalisation, May 2007

2001 Andreas Freytag and Friedrich Schneider, Monetary Commitment, Institutional Constraints and Inflation: Empirical Evidence for OECD Countries since the 1970s, May 2007

2002 Niclas Berggren, Henrik Jordahl and Panu Poutvaara, The Looks of a Winner: Beauty, Gender, and Electoral Success, May 2007

2003 Tomer Blumkin, Yoram Margalioth and Efraim Sadka, Incorporating Affirmative Action into the Welfare State, May 2007

2004 Harrie A. A. Verbon, Migrating Football Players, Transfer Fees and Migration Controls, May 2007 